Meta

Journal des traducteurs

Translators' Journal

\title{
Problems of Translating Nigerian Authors: The Case of Chinua Achebe's No Longer at Ease
}

\section{Ngozi O. Ozulu}

Volume 37, numéro 2, juin 1992

URI : https://id.erudit.org/iderudit/003776ar

DOI : https://doi.org/10.7202/003776ar

Aller au sommaire du numéro

Éditeur(s)

Les Presses de l'Université de Montréal

ISSN

0026-0452 (imprimé)

1492-1421 (numérique)

Découvrir la revue

Citer cet article

Ozulu, N. O. (1992). Problems of Translating Nigerian Authors: The Case of Chinua Achebe's No Longer at Ease. Meta, 37(2), 370-374.

https://doi.org/10.7202/003776ar
Résumé de l'article

À partir de l'étude du roman Le Malaise de Chinua Achebe's, on a essayé d'identifier les problèmes propres à la traduction d'auteurs nigérians. On a découvert que la traduction française de certains termes et de certaines phrases était incorrecte parce qu'il est très difficile de trouver des équivalents stylistiques, sémantiques et pragmatiques français aux africanismes anglais. Les problèmes identifiés touchent donc aux particularités de l'anglais nigérian : problèmes d'aspect et de manque d'uniformité dans l'orthographe du pidgin nigérian et, bien sûr, existence de régionalismes et de termes africanisés ou d'africanismes qui ne figurent pas dans les dictionnaires. 


\title{
PROBLEMS OF TRANSLATING NIGERIAN AUTHORS: THE CASE OF CHINUA ACHEBE'S NO LONGER AT EASE
}

\begin{abstract}
Résumé
À partir de l'étude du roman Le Malaise de Chinua Achebe's, on a essayé d'identifier les problèmes propres à la traduction d'auteurs nigérians. On a découvert que la traduction française de certains termes et de certaines phrases était incorrecte parce qu'il est très difficile de trouver des équivalents stylistiques, sémantiques et pragmatiques français aux africanismes anglais. Les problèmes identifiés touchent donc aux particularités de l' anglais nigérian: problèmes d'aspect et de manque d' uniformité dans l'orthographe du pidgin nigérian et, bien sûr, existence de régionalismes et de termes africanisés ou d'africanismes qui ne figurent pas dans les dictionnaires.
\end{abstract}

\section{ABSTRACT}

Effort was made to identify some specific problems involved in translating Nigerian authors, with Chinua Achebe's No Longer at Ease as a case study. It was discovered that the translation of some terms or phrases were inadequately rendered in French due to the problem of creating a suitably Africanized French stylistically, semantically, and pragmatically equivalent to its Anglophone counterpart. Hence, the problems encountered and identified were the peculiarity of Nigerian English, aspectual problems and non-uniformity in the orthography of Nigerian Pidgin and of course the existence of regionalized and africanized terms or Africanisms which have not found their ways into the dictionaries. 


\section{INTRODUCTION}

This paper discusses the specific problems of translating Nigerian novels from English into French. Specific reference will be made to Chinua Achebe as a "typical Nigerian Author" (Innes and Lindfors 1978). Texts for discussion are drawn from his No Longer at Ease (1980) because it is rich in cultural traits, Africanisms, Nigetian English and Pidgin. Even though Chinua Achebe's books may have been translated into more than thirty languages (Achebe 1983), we shall restrict this study to the problems of translating his works from English to French. Of particular interest to us here is Duclos' French translation of No Longer at Ease entitled Le malaise (Achebe 1974).

Roman Jakobson (1966: 233) distinguished three types of translation namely intralingual, interlingual and intersemiotic translations. Intralingual translation involves rewording in the same language. Interlingual translation involves rewording in another language and is termed "translation proper." Intersemiotic translation is the use of signs by non-verbal sign systems to interpret verbal signs. We are concerned with interlingual translation under which three categories can be distinguished namely: general, literary and scientificitechnical translations. The area of study is literary translation which can be further classified according to the literary genres: poetic, prosaic and theatrical translations. Since No Longer at Ease is a novel, the scope of study will actually be limited to prosaic translation. This goes to prove that prosaic translation is as difficult as poetic or theatrical translations.

\section{SOURCES OF PROBLEMS}

To identify the specific problems involved in translating this novel, it is assumed that there are obviously problems of translation which could be said to be general and linguistic in nature. This paper does not discuss some specific problems which could be peculiar most probably to West Africa as a whole. In analysing the peculiarity of these problems, Eugene Nida's (1966: 1) definition of translating has been retained for two purposes: firstly, because of the question of "dynamic equivalence," and secondly, because of the deficiency of the definition. According to him, "translating consists in producing in the receptor language the closest natural equivalent to the message of the source language, first in meaning and secondly in style." It is important to note that Nida does not include an equivalence in "tone."

The problem of equivalence here is not the presumed endless theories of translatability, untranslatability, possibility or impossibility of translation. In an attempt to resolve these problems, we shall look at them from two perspectives. Suffice it to say that the sociolinguistic and sociocultural perspectives taken have been with the purpose of emphasizing the evolution and adaptability of the two languages in question, to the West African society. These problems are more or less sociolinguistic and sociocultural in nature due to their cultural connotations or africanisation. The varieties of English and Pidgin are sociolinguistic problems whereas Africanisms and other metalinguistic difficulties are sociocultural.

To effectively analyse these problems a panoramic view of three planes on which translation operates shall be studied. They are semantic, stylistic and pragmatic planes (Theanacho 1981: 320). The semantic plane is the "conceptual essence" or rather the content. The stylistic plane deals with the stylistic device or the form, whereas the pragmatic plane is the impression or reaction created on the audience or reader. Here, we will recall Nida's definition of translating which can be said to operate on only two planes - semantic and stylistic, thus leaving out the pragmatic plane. To translate Nigerian writers especially Chinua Achebe would require not only semantic and stylistic equivalences but also pragmatic equivalence. This is because Achebe and a lot of other writers have "Africanized and Nigerianized the English language to achieve their purpose."

\section{SPECIFIC PROBLEMS AND DISCUSSIONS}

The first problem actually is that of varieties of English. The question of varieties of English is not the general view of American English, British English, Autralian English, etc. but varieties of English in Nigeria. Time and space would not permit us to discuss the question of "Nigerian English" or "English Nigeria." No Longer at Ease has language as one of its themes hence varieties of English could be differentiated in the novel. One can distinguish the Standard English from the Africanized English under which Nigerian English and "Igbo English" could be grouped. The Igbo English is the literal translation of Igbo mother tongue into English thus retaining the local syntactic and semantic structures. This is common with Achebe's traditional characters. This of course is due to Achebe's witty manipulation of language which actually is a mark of his originality. Achebe is said to have Africanized the English language most probably because of his African audience and also; it is his stylistic device which brings out the aesthetic qualities in his works.

Looking at the semantic equivalence of certain lexical terms in the novel, they have either been skewed or calqued. In any case, difficulties encountered in translation are first of all lexical in character and are culture-bound terms (Simpson 1981: 51). Some of these terms drawn from the novel and their translations from Le Malaise are: 
bean cakes - des petits pains de haricots nightsoil-man - le balayeur de la rue plantain - le plantain sauvage

been-to - " $j$ 'y suis allée"

These terms are however inadequately translated into French due to lack of the "closest natural equivalent" to the source language terms. Their translations need not be foreign to West Africa. The word, "nightsoil-man" which is synthetic in nature has been translated in an analytical form following Vinay and Darbelnet's (1977: 154) démarche. In the translation of "bean cakes" and "plantain," it can be seen that the translator was aware of an existing Francophone equivalence in West Africa but could not possibly find the appropriate terms. If the equivalence could be found in Francophone Africa, there is no need to either calque or even attempt to create one's own neologisms. Thus the equivalence of these terms are:

\section{bean cakes - des beignets de haricots \\ nightsoil-man - le vidangeur \\ plantain - la banane sauvage}

The equivalence of "been-to" is yet to be given but it is not " $j$ ' y suis allée."

How can the translation of the word "compound" be explained, since two different translators of Achebe gave different translations. Ligny, the translator of Things Fall Apart has two translations for it:

\section{"le domaine" and "le terrain de terre"}

It can be seen that the translator was not really sure of his substitutions because he seemed to have been aware of semantic deficiency in his translations. Nevertheless, Duclos, in Le Malaise, translated the same word as "la concession" which of course is the equivalent. It can be seen that "compound" and "la concession" both have the same effective connotation due to a similar cultural perception in West Africa. For instance, the equivalence of "alligator pepper" calqued as "piment d" alligator" from Things Fall Apart is yet to be given. This has to do with language and cultural conceptualization. We can also compare the translation of the act of "breaking cola" which has interchangeably been rendered as "croquer" or "briser la cola.". These of course are the metalinguistic aspects of the problems of translating Nigerian writers. So far we have been dealing more or less with the lexical characters. Semantic inadequacy in translation can also been seen on the syntactic structure. This requires stylistic competence without distorting its semantic nature.

For instance, a look at the translation of "to accept bribe" and "to eat bribe" as "accepter un pot-de-vin" can be said to be stylistically inadequate since the stylistic aesthetics cannot be easily detected in the French translation. This could be compared with the translation of "We are just throwing money away" as "Nous sommes simplement en train de jeter notre argent par les fenêtres." An attempt has been made to achieve the same stylistic level that would retain the same semantic value of the sentence. However, inadequacy on the semantic plane is not restricted to varieties of English but also to the translation of Pidgin which is the second major problem.

The translation of Pidgin does not only constitute a problem to the translators but even writers have encountered their peculiar problems in inserting Pidgin in their works. Firstly is the problem of comprehension which could result in mistranslation or even "untranslatability". For example the word "tie-tie" in Things Fall Apart (Achebe 1956) was not translated most probably because the translator did not know it is a Pidgin word. Coupled with the problem of understanding the Pidgin language is the lack of a uniform or standard orthography (cf. Ofuani 1981: 329). The insertion of Pidgin serves the purpose of reflecting more accurately the local speech, and also for humouristic purposes. Non-uniformity of orthography in Pidgin could affect the semantic nature of a sentence. For example, these two sentences have been taken from different points of view, making the translation a modulation:

"Too too know na him de worry una."

"Vous savoir trop trop comment déranger quelqu'un."

If the French translation is to be retranslated into Pidgin, we will get:

"Una too dey worry person."

Another problem in Pidgin is that of aspect: "Weting I been de eat all afternoon." - "Quoi moi avoir mangé tout après-midi ?" The duratif nature of the aspect here is not detectable in the translation. However, an attempted solution has been to compare the Camerounian pidgin or "argot camerounais" inserted in Ferdinand Oyono's Une vie de boy (Oyono 1960). Like:

Movié - Mon vieux

Pli d'arcol - Plus d'alcool

On the pragmatic level, however, Pidgin has a comic effect which it tends to lose, if not adequately translated into "petit français." For instance, one of Achebe's characters (Achebe 1960), in an attempt to speak an impressive English and in a bid to avoid Pidgin, eventually mixed up his words: "I can be able to reduce it to two pounds for you." Actually, "can" and "be able to" are synonymous and cannot be used together. This produced a linguistic shock which has a comic effect on the readers. But the French translation, "Je peux vous les réduire en deux 
livres" does not have the same pragmatic value hence it could be said to be pragmatically inadequate to its original. The following translation has been proposed: "Pour vous je peux être en mesure de réduire le prix à deux livres." The pragmatic plane in translation cannot be neglected because American structural linguists see the translator's task as "creating a language structure which would evoke the same reaction in the target-language reader as the original had in its readers," (Kelly 1979: 2).

We cannot neglect the existence of Africanisms, their role in African literature and the problems they constitute not only the reader but also for the translators. Many of the Africanisms are local words borrowed which have remained intact whereas others are creations due to sociolinguistic development of the languages in question. Achebe's style was inspired, influenced and affected by the tradition and culture of the people in question in his novels. It is neither easy nor is it even advisable to translate words like "akara," "Agbada." These are culture-bound words and local colours. But it is however important to understand the cultural connotations attached to each of these terms.

Finally, it would look inappropriate to exclude the problem of audience. This is a peculiar problem since the first audience in the mind of a translator must be that of an African audience. This problem is aggravated as a result of cultural divergencies between the translator and the author, more so if the author is not an African. Could it possibly be that we have not produced enough qualified and capable African translators? But it is of note that even the translators so far, who have translated most African novelists are simply bilingual Europeans, not necessarily trained translators. For example, the majority of Chinua Achebe's novels have been translated by Europeans - Grandsaigne, Ligny, Duclos except for two of his novels translated by Africans - Simpson and D'Almeida.

\section{CONCLUSION}

The major problem has been how to establish or even create a suitably Africanized French stylistically equivalent to its Anglophone counterpart. It has been taken for granted that French is not as dynamic as English so that it is expected that the aesthetic qualities attained by the stylistic sophistication by the writer is almost lost in the French translation. This calls for a comparison of the English title of Achebe's novel "No Longer at Ease" and its French title "Le Malaise". The English title is more like a statement about the general source of discomfort whereas the French title is a single noun which is specific. One could therefore ask if Achebe was not aware of the existence of "malaise" in English or why the translator should choose to transpose a sentence in a single noun. The semantic, stylistic and pragmatic values cannot be said to be equivalent to the original.

Suffice is to say at this juncture that translation studies in Africa have brought into the open the existence of terms outside the dictionaries. It is therefore advisable if lexicographical research could be carried out to further insert these terms or even produce entirely different unilingual dictionaries for West Africa - Anglophone and Francophone. This can further serve as a stepping stone for a bilingual dictionary. Pidgin English could be exploited and its counterpart in Francophone Africa should be developed. Attempts made by some people to write down slangs and Africanized terms should not be undermined. They should rather be encouraged.

NGOzI O. OzULU Bendel State University, Abraka, Nigeria

\section{BIBLIOGRAPHY}

ACHEBE, C. (1958): Things Fall Apart, London, Heinemann.

ACHEBE, C. (1980): No Long at Ease, London, Heinemann.

ACHEBE, C. (1972): Le monde s' effondre, traduit par Michel Ligny, Paris, Présence africaine.

ACHEBE, C. (1974): Le Malaise, traduit par Jocelyn Robert Duclos, Paris, Présence africaine.

BASSNETT-McGUIRE, S. (1980): Translation Studies, London, Methuen.

BROWER, R.A. (Ed.) (1966): On Translation, New York, Oxford University Press.

DUERDEN, D. and C. PIETERSE (Eds.) (1972): African Writers Talking, London, Heinemann.

HALE, T.A. and G.A. PIGEON (1981): "Artist and Audience: The Problems of Africanisms in African Literature of West Expression," Prebe and Hale (Eds.), Artist and Audience, African Literature as a Shared Experience, Washington D.C., Three Continental Press, pp. 77-83.

IHEANACHO, A. (1981): "Translation in Literature and Literature in Translation of the African Writers Situation," The Mission of the Translator Today and Tomorrow, Warsaw.

INNES, C.L. and B. LINDFORS (Eds.) (1973): Critical Perspectives on Chinua Achebe, London, Heinemann.

JAKOBSON, R. (1966): "On Linguistic Aspects of Translation," R.A. Brower (Ed.), On Translation, New York, Oxford University Press, pp. 232-239.

KELLY, L. (1979): The True Interpreter, Oxford, Blackwell. 
MAININ, G. (1963): Les Problèmes théoriques de la traduction, Paris, Gallimard.

NIDA, E. (1966): "Principles of Translating as Exemplified by Bible Translating," R.A. Brower (Ed.), On Translation, New York, Oxford University Press, pp. 11-31.

OFUANI, O.A. (1981): "Pidgin in Nigerian Journalism," Papers in Linguistics 14-3, Edmonton, Canada, Linguistic Research Inc. pp. 327-346.

PACKMAN, B. (1971): "Some Problems of Translation in African Literature," C. Heywood, Perspectives of African Literature, London, Heinemann.

SIMPSON, E. (1981): "The West African Translator Today and Tomorrow," The Mission of the Translator Today and Tomorrow, Warsaw.

The Mission of the Translator Today and Tomorrow, (1981): Warsaw.

The World of Translation, (1971): New York, P.E.N American Center.

UBAHAKWE, E. (Ed.) (1979): Varieties and Functions of English in Nigeria, Ibadan, African Universities Press.

VINAY, J.-P. et J. DARBELNET (1977): Stylistique comparée du français et de l'anglais, Paris, Didier. 